$\mathrm{mmHg}$ )を得た。実測值 $\mathrm{N}=4.89 \%$ ，理論值 $5.00 \%$ 。

Nをメチルアミンと反応させた場合は，やや高収率で Uが得ら

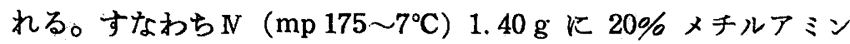
20 倍量を加え， $30 \sim 33^{\circ} \mathrm{C}$ で 1 時間かきまぜ, さらに水 $8.4 \mathrm{~g}$ を 加えて 2 時間かきまぜ, 最後に温度を $55^{\circ} \mathrm{C}$ に上げて 1 時間かき まぜる。生成物を口過し，残留物を $150 \mathrm{cc}$ の $10 \%$ 炭酸カリウ

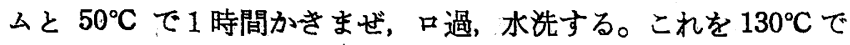
3 時間乾燥し，淡褐色粉末 $1.43 \mathrm{~g}$ を得た。 $\mathrm{N}$ 分析值 $5.02 \%, \mathrm{Cl}$ 分析值 $25.04 \%$ （理論値 $25.31 \%$ ）で純度は良好であり，ベンゼ ンと酢酸エチルの等容混合物より再結晶し, $\mathrm{mp} 230^{\circ} \mathrm{C}$ (補正) の メチルイミド $1.18 \mathrm{~g}$ を得た。対理論収率 $80.3 \%$ 。

\section{3,5-ジクロルナフタル-N-メチルイミドとベンゾアントロ ンとの縮合}

$2 \cdot 1$ 温度および時間によるA型色素の収率之塩素含量の変化

$\mathrm{V}$ とXそれぞれ $2 / 1000 \mathrm{~mol}$ の等モル混合物を $95^{\circ} \mathrm{C}$ の場合, Xの 45 倍量の無水エタノールと 5 倍量のナトリウムよりなるエ チラート溶液中で, また $107^{\circ} \mathrm{C}$ では約 41 倍量の無水エタノール と 5 倍量のナトリウムよりなるエチラート溶液中で，さらに 117 ${ }^{\circ} \mathrm{C}$ 以上は $n$-ブタノール 65 倍量と 5 倍量のナトリウムよりなる ブチラート溶夜中で反応させ, 以下前報と全く同様に処理してメ タノール可溶分, ベンゼン可溶分, ベンゼン不溶分 (A 型色素) を分取し，A型色素の収率および塩素含量を決定した。塩素分析 はミクロボンベ法によった。これらの結果を表 1 および図 4 に示 す。

UとXの反応は 3,4,5-トリクロルナフタル-N-メチルイミド と，Xとの縮合反応の場合にくらべ，さらにすみやかであり，反 応開始後, 短時間の間に溶液は青紫色を呈する。この色は時間の 経過に伴ない純紫色となり，さらに赤紫色に変ずる。この変化は $\mathrm{BPM}$ モノクロル誘導体よりの塩素の脱離によるすのと考えられ るが，生成したA型色素の塩素分析結果もこの事実を明らかにし ている。

$2 \cdot 2$ 3,5-ジクロルおよび 4-クロルナフタル-N-メチルイミド とベンソアントロンとの反応 $\mathrm{U} の \beta$ 位塩素の樎合に拈よほすす

\begin{tabular}{|c|c|c|c|c|c|c|c|c|c|}
\hline \multirow{2}{*}{ No. } & \multirow{2}{*}{\multicolumn{2}{|c|}{$\begin{array}{l}\text { 溶 媒 } \\
\text { (P) }\end{array}$}} & \multirow{2}{*}{$\begin{array}{l}\text { 反岕 } \\
\text { 温度 } \\
\left({ }^{\circ} \mathrm{C}\right)\end{array}$} & \multirow{2}{*}{$\begin{array}{c}\text { 反芯 } \\
\text { 時佃 } \\
\text { (min) }\end{array}$} & \multicolumn{3}{|c|}{ アルカリ不溶分組成 } & \multicolumn{2}{|c|}{ A 型色絭 } \\
\hline & & & & & \multirow{2}{*}{$\frac{\begin{array}{c}\mathrm{MeOH} \\
\text { 可溶 }(\%)\end{array}}{37.0}$} & \multirow{2}{*}{$\frac{\mathrm{C}_{6} \mathrm{H}_{0}}{\text { 可溶 }(\%)}$} & \multirow{2}{*}{$\frac{\begin{array}{c}\text { A 型急 } \\
\text { 意(\%) }\end{array}}{9.4}$} & \multirow{2}{*}{$\begin{array}{c}\text { 収帮*2 } \\
(\%)\end{array}$} & \multirow{2}{*}{$\mathrm{Cl} \%$} \\
\hline 1 & EtOH & 45 & 95 & 15 & & & & & \\
\hline $2 * 1$ & " & 50 & " & 270 & 35.7 & 52.1 & 12.2 & 11.8 & - \\
\hline 3 & " & 41 & 107 & 7 & 34.6 & 41.6 & 23.8 & 24.0 & 6.91 \\
\hline 4 & " & 11 & "! & 10 & 23.9 & 44.8 & 31.3 & 31.7 & 7.46 \\
\hline 5 & " & 11 & " & 15 & 33.1 & 37.4 & 29.5 & 30.5 & 6.74 \\
\hline 6 & "I & $" 1$ & $"$ & 60 & 24.6 & 47.7 & 27.7 & 29.4 & 2.60 \\
\hline 7 & $\mathrm{BuOH}$ & 65 & 117 & 15 & 24.4 & 32.0 & 43.6 & 42.2 & $5.82 * 3$ \\
\hline 8 & " & $" 1$ & "! & 20 & 30.6 & 24.1 & 45.3 & 45.0 & 5.52 \\
\hline 9 & " & " & $"$ & 25 & 27.2 & 26.9 & 45.9 & 44.9 & 5.03 \\
\hline 10 & " & " & "I & 60 & 28.9 & 32.1 & 39.0 & 35.7 & 3.49 \\
\hline 11 & " & " & 125 & 5 & 43.0 & 21.8 & 35.2 & 35.1 & 6.46 \\
\hline 12 & " & " & " & 10 & 43.2 & 16.8 & 40.0 & 38.2 & 5.17 \\
\hline 13 & " & " & " & 15 & 29.0 & 21.6 & 49.4 & 47.8 & 3.98 \\
\hline 14 & " & " & " & 20 & 33.1 & 17.9 & 49.0 & 46.0 & - \\
\hline 15 & " & $" 1$ & "I & 40 & 23.1 & 33.0 & 43.9 & 33.3 & - \\
\hline $16^{* 1}$ & $"$ & 78 & 117 & 20 & 19.4 & 22.8 & 57.8 & 55.3 & 5.08 \\
\hline $\begin{array}{l}* 1 \\
* 3\end{array}$ & $\begin{array}{l}\mathrm{Na} \text { 量= } \\
\mathrm{N} \%=2 .\end{array}$ & $\begin{array}{l}=\mathrm{XX} \\
96\end{array}$ & & $\tau$ & ロル B & $I(M=4$ & $71.7)$ & 村する & 收取 \\
\hline
\end{tabular}

\begin{tabular}{|c|c|c|c|c|c|c|}
\hline \multirow{4}{*}{$\begin{array}{l}\text { Nーメチ } \\
\text { ルイミド }\end{array}$} & \multirow{2}{*}{\multicolumn{2}{|c|}{ 表 }} & \multicolumn{2}{|c|}{2} & \multirow[b]{2}{*}{ （時間 } & \multirow[b]{2}{*}{$15 \mathrm{~min})$} \\
\hline & & & & & & \\
\hline & \multirow{2}{*}{$\begin{array}{c}\mathrm{Na} \text { 量 } \\
\text { (P) }\end{array}$} & \multirow[b]{2}{*}{$\begin{array}{c}\text { 温 目 } \\
\left({ }^{\circ} \mathrm{C}\right)\end{array}$} & \multicolumn{3}{|c|}{ アルカリ不溶分組成 } & \multirow{2}{*}{$\begin{array}{c}\text { A型急 } \\
\text { 类杵 } \\
(\%)\end{array}$} \\
\hline & & & $\begin{array}{c}\mathrm{MeOH} \\
\text { 可溶(\%) }\end{array}$ & $\begin{array}{c}\mathrm{C}_{6} \mathrm{H}_{\mathrm{B}} \\
\text { ，可溶 }(\%)\end{array}$ & $\begin{array}{c}\text { A型急亲 } \\
(\%)\end{array}$ & \\
\hline II & 5.0 & 107 & 33.1 & 37.4 & 29.5 & 30.5 \\
\hline 4ークロル & $" 1$ & " & 42.8 & 43.3 & 13.9 & 14.5 \\
\hline V & $" \prime$ & 117 & 24.4 & 32.0 & 43.6 & 42.2 \\
\hline 4ークロル & 6.0 & $"$ & 33.2 & 45.6 & 21.2 & 21.2 \\
\hline
\end{tabular}

効果を明らかにするために, $107^{\circ} \mathrm{C}, 117^{\circ} \mathrm{C} て ゙ 15$ 分の反応を行な い,4-クロル誘導体とXの縮合反応と比較した。この結果を表 2 に示す。

（日本化学会第 13 年会一部講演）

本研究における赤外分光分析に関し，助言ならびに協力を頂い た東大工学部応用化学科, 田中誠之講師に深謝し，また原料を頂 いた八幡化学工業株式会社, ならびに三井化学工業株式会社に対 して謝意を表します。また実験の一部は当所技術研究生, 林寿源 君の協力によった。な打研究費の一部は炤和 35 年度, 文部省綜 合研究費による。

\title{
塩素化によるアクリロニトリルの 精製
}

(昭和 36 年 1 月 27 日受理)

$$
\text { 秦 弘 }{ }^{*}
$$

ニュウランド触媒により合成した粗アクリロニトリルの精製法として，不純物を高沸点塩素化合物として除去する方法 について検討した。金属酸化物と塩酸の組み合せで二酸化マンガンを使用した場合は，好結果が得られることを見出し た。また不純物をクロルヒドリンとして除去する方法は, いずれの方法も効率が低い。さらに硫酸の存在下に塩素ガスを 通じる方法を検討し，塩素ガスのみを使用するよりすすぐれた方法であることを見出した。

\section{1 緒言}

ニュウランド触媒により合成したアクリロニトリル (AN) の 精製法としては種々の方法が報告されているが1)，ハロゲンによ

* 日東理化学研究所: 浦和市上木崎.

1）神原 “アクリロニトリル——その化学と工業” p. 11〜14 技報堂.
る方法22は比較的好結果をしめすが，合成㵶維原料とする高純度 の AN を得ることは困難である。著者らはさきに AN の精製法 について報告し ${ }^{9}$ ，クロム酸酸化法4)が合成㵶維原料を得る方法 としてすぐれたものであることをのべたが，この方法に使用する 2） A.C.C., 特公 昭 26-1708, U.S.P. 2, 382, 383 (1945).

3) 秦, 有富, 岡部, 工化 64,337 (1961).

4) 秦, 岡田, 岡部, 有富, 工化 64,1121 (1961). 
原料 AN は水添加共沸蒸留等の前操作が必要であり，また処理 AN が重合し易い等の久点があり, さらに他法の検討が必要であ る。

ハロゲン化法は AN のハロゲンに刘する反応性の少ないこと を利用し，不純物を高沸点塩素化合物として除去するものであ り，この特性を利用すれば不純物を塩素化合物として除去する方 法が見出せるのではないかと考えた。

\section{2 試料および判定法}

本奉験に使用した粗 AN の組成は表1にしめすものである。

裴 1 原料粗 AN の組成

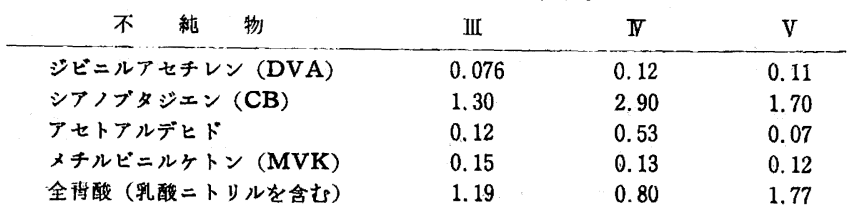

処理 $\mathrm{AN}$ は分留して留分 1 打よび 2 は各 10\%，3５ は各 20 \%，残りは後留とし各留分は粗 AN に対する容量\%でしめし， 各留分の不純物を分析し，全項目に合格した留分を製品とした。 合格留分は DNA $0.00002 \%$ 以下, 全青酸 $0.01 \%$ 以下, アセ卜 アルデヒド $0.02 \%$ 以下, MVK 0.0003\% 以下, 紫外吸収スペク トル怙よびブロム消費速度が純 AN と同程度のものである。表 中には不合格留分のみ記載した。

\section{3 実験および結果の検討}

\section{$3 \cdot 1$ 金属酸化物と塩酸による精製}

金属酸化物と塩酸により塩素が生成することは一般によく知ら れており，ここに生成した塩素を利用すれば比較的温和に反応が 進行し，主として不純物のみが塩素化されることが期待される。 さらに金属酸化物の酸化力を利用できれば, カルボニル化合物の 除去も可能ではないかと考えられる。

粗 AN-III $100 \mathrm{cc}$ に金属酸化物を添加し, かきまぜがら室温 で濃塩酸 $13.2 \mathrm{cc}$ を滴下し, 全反応時間を 6 時間とし, AN 層を 分離して水 $50 \mathrm{cc}$ を加え，ウィドマ一分留管を使用して共沸蒸留 して各留分について品質検定を行ない, 表2を得た。使用した酸 化物は二酸化マンガンを基準として, 次式を想定して求めたすの である。

$$
\mathrm{MnO}_{2}+4 \mathrm{HCl} \longrightarrow \mathrm{MnCl}_{2}+\mathrm{Cl}_{2}+2 \mathrm{H}_{2} \mathrm{O}
$$

表 2 から $\mathrm{MnO}_{2}, \mathrm{CrO}_{3}$ 扎よび $\mathrm{PbO}_{2}$ が好結果をしめすことを 見出した。 $\mathrm{CrO}_{3}$ が効果があるのは酸化反応子相当関与している と考えられ，留出 AN 中にはカルボニル化合物の検出はでさな い。精製収率が恶いのは DVA 扎よび青酸の除去が不十分であ 丧 2 金属酸化物と壏酸に上る精製

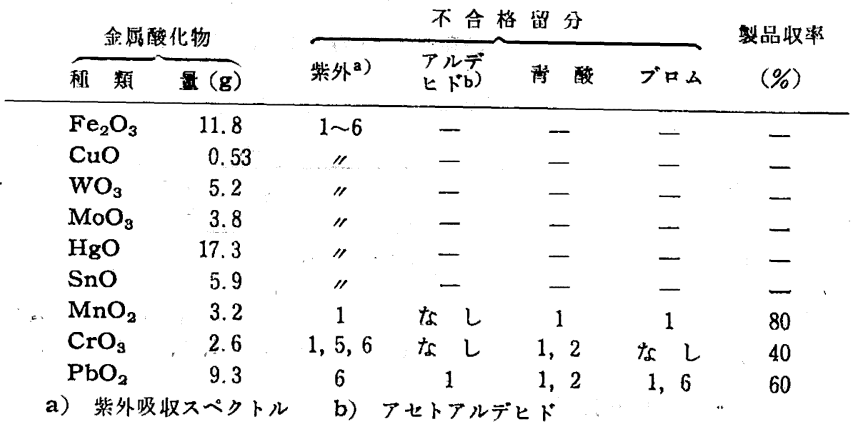

り，さらに後留中に未確認不純物を含むためである。 $\mathrm{MnO}_{2}$ およ び $\mathrm{PbO}_{2}$ はこの条件では酸化は起り難いと考えられるので，精製 効果は主として塩素によるものと考えられる。この両者では $\mathrm{MnO}_{2}$ の方が多少すぐれた結果をしめしている。他の金属酸化物ではほ とんど精製効果は認められず，この条件では塩素を生成しないた めと考えられる。

\section{$3 \cdot 2$ 二酸化マンガン一塩酸系による精製}

$\mathrm{MnO}_{2}-\mathrm{HCl}$ 系で好結果が得られたので，この方法による条件 の検討を行なった。

粗 AN-III を水蒸気蒸留し初留 20\% を除いた主留 70\%を原 料とし，このもの $150 \mathrm{cc}$ を処理し, $\mathrm{AN}$ 層を分離して水 $70 \mathrm{cc}$ を加えウイドマー分留管で共沸蒸留し，表了を得た。

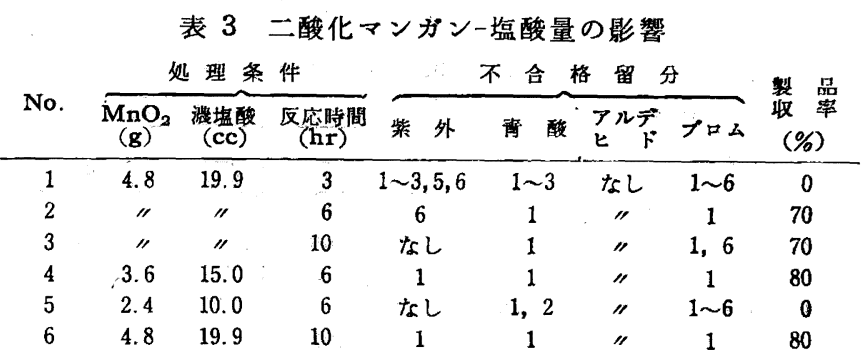

No. 1 では反応時間が不足であり DVA が前留中に認められ, 5 では試楽量が不足で不純物の除去が十分でない。すなわち $\mathrm{Mn}$ $\mathrm{O}_{2}-\mathrm{HCl}$ 系では塩素発生が完全に終るには 6 時間以上が 必要であ り；試薬量は原料 AN の純度により変わるが最適量がある。6 は水蒸気蒸留した前留分 90\% を使用した場合であり, 留出 $\mathrm{AN}$ 中には DVA は認められず, この方法で完全に除去されることを しめしている。

以上の実験で後留分の紫外吸収スペクトルを測定した場合, 未 確認の不純物の吸収が認められ，製品の純度を低下させることが あるが，これは塩素化された化合物が蒸留中に熱分解されて留出 してくるためと考えられる。そこで 2 と同様に処理した AN に ついて，蒸留方法と製品純度の関係を検討し表 4 を得た。

表 4 蒸留方法による影響

\begin{tabular}{|c|c|c|c|c|c|c|c|c|c|}
\hline \multirow{2}{*}{ No. } & \multirow{2}{*}{\multicolumn{2}{|c|}{ 蒸 留 方 }} & \multirow{2}{*}{ 法 } & \multicolumn{5}{|c|}{ 不合格留分 } & \multirow{2}{*}{$\begin{array}{l}\text { 慗品 } \\
\text { 品 } \\
\text { (\%) }\end{array}$} \\
\hline & & & & 紫 外 & 青 & 酸 & アルデ & ブャム & \\
\hline 1 & ウィド & 又一分会 & 留管 & 6 & & 1 & 1 & 6 & 70 \\
\hline 2 & & " & 水50\%添扠 & なし & & 1 & 1 & なし & 80 \\
\hline 3 & 精留塔 & （理歌 & 段数10段） & 1 & & 1 & なし & $1,5,6$ & 50 \\
\hline 4 & $"$ & " & ＂水 $50 \%$ 添加 & 1 & & 1 & なL & 6 & 70 \\
\hline
\end{tabular}

表 4 から処理 AN をそのまま蒸留した場合は，水添加共沸蒸 留した場合より後留分中のブロム消費物質が少なく, ウィドマー 分留管を使用した方が精留塔より製品収率が高い。このことは高 温長時間の加熱は塩素化合物の分解を促進し，ブロムを消費する 不飽和化合物を生成し製品の純度を低下させるためと考えられ， 本法による精製においてはできるだけ低温で蒸留することが望ま しい。処理 AN は蒸留中に重合することがあるが、ヨウ化カリ むるいは塩化第一銅を重合防止剂として使用すれば容易に防止可 能であり,クロム酸酸化精製法のような問題はない。

$\mathrm{MnO}_{2}$ に対する塩酸の使用量は前記反応による塩素生成である とすれば，過剩の塩酸は製品の品質に悪影鳘を执よばすはすであ り，計算量より20\% 過剩に使用した場合表 5 が得られた。 No. 1 は計算量であり， 2 は $20 \%$ 過剩に塩酸を使用した場合 


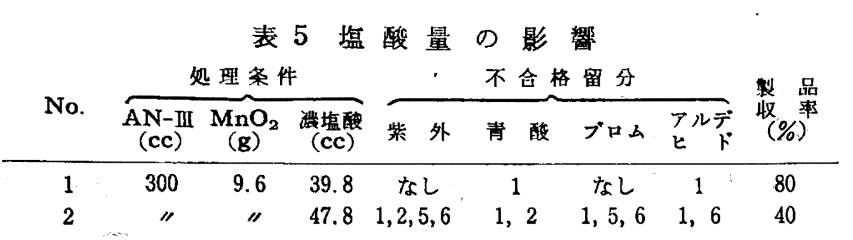

であり，いずれの試験です品質は低下する。

$\mathrm{MnO}_{2}-\mathrm{HCl}$ 法は処理条件が適当であれば高純度の合成䋐維原 料を得る精製法として有力であることが明らかとなったが，表 1 のように組成の異なったものについても適用でさるかどうかを知 るために, 粗 AN を水蒸気蒸留して前留分 $20 \%$ を除いた主留 $70 \%$ を原料とし，このもの $100 \mathrm{cc}$ を使用し，室温で 10 洔間処 理して分留し表 6 を得た。蒸留はウィドマー分留管を使用した。

表 6 原料組成による影響

\begin{tabular}{|c|c|c|c|c|c|c|c|c|c|}
\hline \multirow[b]{2}{*}{ No. } & \multirow{2}{*}{$\begin{array}{c}\text { 粗 } \\
\mathrm{AN}\end{array}$} & \multirow{2}{*}{$\begin{array}{c}\mathrm{MnO}_{2} \\
(\mathrm{~g})\end{array}$} & \multirow{2}{*}{$\begin{array}{c}\text { 渄塭酸 } \\
\text { (cc) }\end{array}$} & \multirow[b]{2}{*}{ 蒸留方法 } & \multicolumn{4}{|c|}{ 不合格留分 } & \\
\hline & & & & & 柴 外 & 青 酸 & ブロム & $\begin{array}{l}\text { アルデ } \\
\text { ヒ }\end{array}$ & \\
\hline 1 & III & 3.2 & 13.3 & 水添加共沸 ${ }^{\mathrm{a})}$ & なし & 1 & なし & 1 & \\
\hline 2 & $\bar{N}$ & 4. & 19.9 & "I & $1,5,6$ & 1 & - & - & \\
\hline 3 & V & "I & I" & "I & 1,6 & 1,2 & - & - & \\
\hline 4 & $\mathbb{N}$ & " & "I & 減圧蒸留 1 回b) & 6 & なし & 1 & 1 & \\
\hline 5 & $\nabla$ & " & "I & II & 6 . & なし & なし & 1 & \\
\hline 6 & N & $"$ & $"$ & 減正蒸留 2 回 & 6 & 1 & なし & 1 & \\
\hline 7 & $\mathrm{~V}$ & " & $"$ & "I & 6 & なし & なし & 1 & \\
\hline
\end{tabular}

a) 处理 AN 飞対し $50 \%$ 容量の水を使用

b) $300 \mathrm{mmHg}$ Kて蒸留

原料粗 $\mathrm{AN}$ のIII $\mathrm{V}$ の組成はかなりの差があり， V の製品収 率が低いのは当然であろう。とNでは比較的差が少なく, 全青 酸すなわち乳酸ニトリル (LN) の含量が多くなっているが, 同一

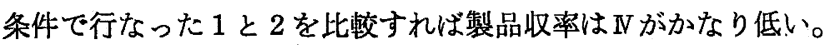
試薬量はそれそれこの条件に括ける最適量であり, この差が LN に起因するのではないかと考え，硫酸を添加しNより水蒸気蒸留 でLN を安定化して除去したものについて同様に突験したが，収 率の向上は認められず原因は不明である。またN抽よびVを原料 とした場合の製品収率が低いのは，後留分中に紫外部に吸収を持 つ化合物が含まれているためであり，このるのは塩素化された化 合物が，蒸留中に分解されて留出してくるためと考えられ，加熱 分解を执さえるため $300 \mathrm{mmHg}$ の減圧下に蒸留したところ，4〜 7 のように製品の収率が向上した。

\section{$3 \cdot 3$ クロルヒドリン法}

粗 AN 中には DVA， CB および MVK のような不飽和化合 物を含有しており，これらをクロルヒドリンとして除去する方法 を試みた。

粗 AN-而 $300 \mathrm{cc}$ に漂白粉と水を加光，かきせぜがら硫酸水 溶液を滴下または炭酸ガスを送入しながら8 時間反応させ，反応 液より $\mathrm{AN}$ 層を分離して理諭段数 $1 \sim 2$ 段程度のウィドマー分 留管を使用して蒸留し, 留出 AN の純度を検定し表 7 を得た。

粗 AN-III:の不飽和不純物は約 $0.07 \mathrm{~mol}$ (100 cc 中) を含み, さらにアセトアルデヒド，青酸叔よび $\mathrm{LN}$ 等を含み，これらを合 せると $0.1 \mathrm{~mol}$ 程度となる。クロルヒドリン源として使用した 漂白粉は有効塩素 35\%であり，100 $\mathrm{g}$ より $1 \mathrm{~mol}$ のクロルヒド リンを生成する計算になる。

表 7 がしめすょ 5 にの方法では紫外，アルデヒドの成績が悪 く，DVA 怙よびアセトアルデとドの除去は困難である。

粗 AN-III $300 \mathrm{cc}$ に炭酸カルシウムと水を加光，かきをぜなが
表 7 漂白粉による方法

\begin{tabular}{|c|c|c|c|c|c|c|c|}
\hline \multirow[b]{2}{*}{ No. } & \multicolumn{3}{|c|}{ 倵薬 } & \multicolumn{3}{|c|}{ 不合格留分 } & \multirow{2}{*}{$\begin{array}{c}\text { 製品収率 } \\
(\%)\end{array}$} \\
\hline & $\begin{array}{c}\text { 漂白粉 } \\
(\mathbf{g})\end{array}$ & $\begin{array}{l}\text { 水 } \\
(\mathbf{g})\end{array}$ & 酸 & 紫 外 & 青 酸 & $\begin{array}{l}\text { アルデ } \\
\text { 七 }\end{array}$ & \\
\hline 1 & 45 & 220 & 硫一酸 & $1 \sim 6$ & 1,2 & $1 \sim 6$ & 0 \\
\hline 2 & 30 & 100 & 湠酸ガス & $1 \sim 6$ & 1 & $1 \sim 6$ & 0 \\
\hline 3 & 30 & 250 & " & $1 \sim 6$ & 1 & $1 \sim 6$ & 0 \\
\hline 4 & 40 & 300 & $" \prime$ & $1 \sim 6$ & 1 & $1 \sim 6$ & 0 \\
\hline
\end{tabular}

表 8 炭酸カルシウムー水一塩素による方法

\begin{tabular}{|c|c|c|c|c|c|c|c|}
\hline \multirow[b]{2}{*}{ No. } & \multicolumn{3}{|c|}{ 薬 } & \multicolumn{3}{|c|}{ 不合格留分 } & \multirow{2}{*}{$\begin{array}{c}\text { 㡀品収率 } \\
(\%) \\
\end{array}$} \\
\hline & $\begin{array}{l}\text { 栄酸カルン } \\
\text { ヴ (g) }\end{array}$ & (c) & 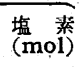 & 柴 外 & 青 酸 & $\begin{array}{l}\text { アルテ } \\
\text { ヒ }\end{array}$ & \\
\hline 1 & 50 & 200 & 0.60 & $1 \sim 6$ & な. & $1 \sim 6$ & 0 \\
\hline 2 & 30 & " & 0.38 & 5,6 & 1,2 & 1,2 & 40 \\
\hline 3 & 15 & "I & 0.38 & $1,3 \sim 6$ & $1 \sim 4$ & $1 \sim 6$ & 0 \\
\hline 4 & 15 & " & 0.19 & $1 \sim 6$ & 1,2 & 1,2 & 0 \\
\hline
\end{tabular}

ら塩素ガスを通じてクロルヒドリンを生成させながら反応する方 法を試みた。反応温度は常温であり時間は8 時間で，処理 AN を水蒸気蒸留してウィドマー分留した場合表 8 を得た。

漂白粉の場合より DVA およびアルデヒドの除去効果は向上し ており，No. 2 では 40\% の製品が得られた。また塩素導入量に は最適量があり，余り過利に使用すれば製品の収率は低下寸る。 この方法は製品の純度のみについては精製法として採用し得る可 能性があるが, 前記 $\mathrm{MnO}_{2}-\mathrm{HCl}$ 法に比較し収率が低い。

粗 AN-III $300 \mathrm{cc}$ に水 $200 \mathrm{cc}$ を加方，かきま゙ながら常温で 塩素ガスを通じながら 8 時間反応させ，前記方法と同様に処理し て表 9 を得た。

\begin{tabular}{|c|c|c|c|c|c|c|}
\hline \multirow[b]{2}{*}{ No. } & \multirow{2}{*}{$\begin{array}{l}\text { 塩 䋕 } \\
(\mathrm{mol})\end{array}$} & \multicolumn{3}{|c|}{$\begin{array}{r}\text { 表 } 9 \text { 水-塩素 } \\
\text { 不合格留分 }\end{array}$} & \multirow{2}{*}{$\begin{array}{l}\text { による る } \\
\text { アルデ } \\
\text { ア收品杵 }\end{array}$} & \multirow[t]{2}{*}{ 法 } \\
\hline & & 柴 外 & 青 酸 & $\begin{array}{l}\text { アルデ } \\
\text { 七 }\end{array}$ & & \\
\hline 1 & 0.60 & 5,6 & 1,2 & 1 & 40 & ウィドマー分留管 \\
\hline 2 & "I & なし & 1,2 & なし & 40 & 精留塔(理諭段数 10 段) \\
\hline 3 & 0.38 & $4 \sim 5$ & 1,2 & 1,2 & 20 & ウィドマー分留管 \\
\hline 4 & " & 1 & $1 \sim 6$ & $1 \sim 6$ & 0 & 䊑留塔 (理諭段数 $10 \varepsilon^{-}$) \\
\hline 5 & 0.19 & $1 \sim 6$ & 1 & $1 \sim 3$ & 0 & ウィドマー分留管 \\
\hline
\end{tabular}

水一塩素でも炭酸カルシウム一塩素々同程度の精製効果が見られ た。これらはいずれの方法でもクロルヒドリンとして不飽和化合 物を除去していると考えられるが，反応生成物については確認し ていない。塩素の反応性を考えると，当然塩素付加も起っている ことが考えられるので比較のため篮素のみによる方法を検討し た。

粗 AN-III $300 \mathrm{cc}$ に常温で塩素を通じつつ，8時間反応させ表 9 の場合と同様に処理し表 10 を得た。表中の No. 4 はアルカリ の存在下に和ける塩素化精製法らの追試を行なったものである。

表 7〜10は試楽以外は同一条件であり, 表 10 では紫外部に吸 収を持つ化合物の除去も表 9 の塩素-水による方法よりも幾分昰 くなっている。これは塩素化のみで不飽和化合物を除去するよ り，クロルヒドリンとして除去する方が効果的なことを示してい

\begin{tabular}{|c|c|c|c|c|c|c|}
\hline \multirow[b]{2}{*}{ No. } & \multicolumn{2}{|c|}{$\begin{array}{l}\text { 表 } 10 \\
\text { 武 桬 }\end{array}$} & 素 に & $\begin{array}{l}\text { る 方 } \\
\text { 合格留 }\end{array}$ & $\begin{array}{l}\text { 法 } \\
\text { 分 }\end{array}$ & \multirow{2}{*}{$\begin{array}{c}\text { 製品収铔 } \\
(\%)\end{array}$} \\
\hline & $\begin{array}{l}\text { 盐 } \\
(\mathrm{mol})\end{array}$ & $\begin{array}{l}\text { 炭酸ソー } \\
\text { ダ (g) }\end{array}$ & 柴 外 & 輩 酸 & $\begin{array}{l}\text { Tル } \\
\text { t }\end{array}$ & \\
\hline 1 & 0.60 & - & 5,6 & $1,5,6$ & $1 \sim 6$ & 0 \\
\hline 2 & 0.38 & - & 1 & $1,5,6$ & $1 \sim 6$ & 0 \\
\hline 3 & 0.19 & - & $1 \sim 6$ & 1 & $1 \sim 6$ & 0 \\
\hline 4 & 0.38 & 1.0 & 1 & $1 \sim 3$ & $1,2,4 \sim 6$ & 0 \\
\hline
\end{tabular}

5) D. R.P. 851,347 . 
る。使用塩素量が多い晹合は (No. 1) DVA は完全に除去されて いるが，試薬量が多く AN 等の塩素化も括こり，後留中にこれ ら塩素化物の熱分解生成物之考えられる不純物の生成が見られ る。このことはまたクロルヒドリン法でも塩素化が起っている可 能性をしめするのであるが，生成物の確認を行なっていないので 詳細は不明である。

クロルヒドリン法が塩素法と異なる他の点はアセトアルデヒド の除去効果であり，一般に両法ともにアルデヒドの除去効果は低 いが，特に塩素のみの場合はいずれの条件に拈いても全留分中に アルデヒドが検出される。これに反し丞塩素法はもっとも効果 が高く，表 9 の No. 2 ではどの留分にもアルデヒドの検出はで きない。アセトアルデヒドは沸点が低く本実験の蒸留条件では前 留中に留出するので, 後留中のものは乳酸ニトリルの分解により 生成したものと考觉られるが，クロルヒドリン法の方が塩素のみ の場合より，乳酸ニトリルを安定化するためではないかと考えら れるがその詳細な機構は不明である。

\section{4 硫酸存在下に塩素を通じる方法}

粗 AN の精製法を検討するにあたり，著者らは硫酸の存在が 特異な効果をしめすことをしばしば経験した。クロルヒドリン法 は中性で反応させる方法になるが，この特異性を利用し硫酸の存 在下で塩素を通じる方法を検討した。

粗 $\mathrm{AN}-\mathrm{III} 300 \mathrm{cc}$ に適当な濃度の硫酸溶液を加え，かきまぜな がら常温で所定量の塩素ガスを 2 時間で送入し，さらに 1 時間同

表 11 硫酸の存在下に塩素を通じる方法-1

\begin{tabular}{|c|c|c|c|c|c|c|c|}
\hline \multirow{2}{*}{ No. } & \multicolumn{3}{|c|}{ 試狜 } & \multicolumn{3}{|c|}{ 不 合 格 留 分 } & \multirow{2}{*}{$\begin{array}{c}\text { 製品収率 } \\
(\%) \\
\text { (\%) }\end{array}$} \\
\hline & $\begin{array}{c}\text { 漰硫酸 } \\
\text { (cc) }\end{array}$ & $\begin{array}{l}\text { 水 } \\
\text { (cc) }\end{array}$ & $\begin{array}{l}\text { 㙁' 恝 } \\
\text { (mol) }\end{array}$ & 柴 外 & 竹 酸 & $\begin{array}{l}\text { アルデ } \\
\text { ヒ }\end{array}$ & \\
\hline 1 & 30 & 60 & 0.60 & 4,5 & 1,2 & $1 \sim 6$ & 0 \\
\hline 2 & "I & 11 & 0.38 & なし & 1 & $1 \sim 6$ & 0 \\
\hline 3 & 11 & " & 0.19 & $1 \sim 6$ & 1 & $1 \sim 6$ & 0 \\
\hline 4 & " & 30 & 0.60 & 5,6 & 1 & 1 & 60 \\
\hline 5 & " & 11 & 0.38 & 5,6 & 1 & 1 & 60 \\
\hline 6 & $"$ & 11 & 0.19 & なし & 1 & 1 & 80 \\
\hline 7 & 11. & 20 & $" 1$ & なし & 1 & 1 & 80 \\
\hline 8 & 11 & 10 & 11 & なし & 1 & 1 & 80 \\
\hline
\end{tabular}

表 12 硫酸存在下に塩素を通じる方法 -2

\begin{tabular}{|c|c|c|c|c|c|c|c|}
\hline \multirow[b]{2}{*}{ No. } & \multicolumn{3}{|c|}{ 試：楽 } & \multicolumn{3}{|c|}{ 不合格留分 } & \multirow{2}{*}{$\begin{array}{c}\text { 製品收率 } \\
(\%)\end{array}$} \\
\hline & $\begin{array}{c}\text { 瀷硫酸 } \\
(\mathbf{c c})\end{array}$ & 水 & $\begin{array}{l}\text { 坆 } \\
\text { (mol }\end{array}$ & 紫 外 & 青 酸 & $\begin{array}{l}\text { アルデ } \\
\text { ヒ } \quad \text { ト }\end{array}$ & \\
\hline 1 & 40 & 20 & 0.38 & なし & 1 & 1 & 80 \\
\hline 2 & 20 & 30 & II & 1 & 1 & $1 \sim 6$ & 0 \\
\hline 3 & 11 & 10 & $"$ & 5 & 1 & 1,2 & 40 \\
\hline 4 & " & 0 & "I & なし & 1 & 1 & 80 \\
\hline 5 & il & "I & 0.19 & 1,2 & 1,2 & $1 \sim 3$ & 20 \\
\hline 6 & 15 & 30 & 0.38 & なし & 1,2 & $1 \sim 6$ & 0 \\
\hline 7 & " & 15 & "I & 1 & 1 & 1,2 & 40 \\
\hline 8 & $" 1$ & 0 & "I & 1 & 1 & 1,2 & 40 \\
\hline 9 & 10 & - I" & " & 1 & 1 & $1 \sim 3$ & 20 \\
\hline
\end{tabular}

条件で反応させて後 $\mathrm{AN}$ 層を分離し，フェンスケ型精留塔（理 論段数 10 段）で精留し，各留分中の不純物を分析した結果表 11 扣よび 12 が得られた。

表 11 は硫酸濃度と塩素量の関係をしめしたものであり, 硫酸 濃度が低い場合はアルデヒドの除去が不十分であり，製品となる 留分が得られないが，50 vol\%以上では好収率で得られ，No. 6 では 80\% が製品となる。この条件では紫外部に吸収を持つ DVA 等は容易に除去され，前記クロルヒドリン法扎よび塩素法 と比較し，不純物の除去が容易である。また使用塩素の量す最適 量が存在するが, その量は前記二法に比較して少なくてよい。

表 12 は硫酸量の影響について検討したものであり, 硫酸の量 が少ない場合は硫酸濃度を高くする必要があると同時に, 塩素量 が多くなる。すなわち硫酸量と塩素量の間には相関関係があり， 工業的立場からは表 11 の 6 7 の条件が有利である。硫酸量が 少なくなると不純物の除去に必要な量に対する塩素の過㮃率が增 加し，AN の塩素化による損失が多くなり好ましくない。

不純物を塩素化合物として除去する以上の三法において, 酸化 法と比較して不飽和化合物とくにDVA の除去効果はすぐれてお り，処理 AN 中には DVA はほとんど認められない。一方アセ トアルデヒドの除去効果は, 酸化法に比して弱く三法とあに钽量 の残存が認められるが, $\mathrm{MnO}_{2}-\mathrm{HCl}$ 法では比較的効果がよく, アルデヒドの除去法としても有効であるが，これは塩素ガスによ る方法では分子状として反応するのに対し， $\mathrm{MnO}_{2}-\mathrm{HCl}$ 法では 活性塩素によるものではないかと考えられる。硫酸存在下塩素ガ スを通じる方法は，硫酸による乳酸ニトリルの安定化効果が大き いためであろろ。

\section{4 総括}

ニュウランド触媒により合成した粗アクリロニ小リルの精製法 として，不純物を高沸点塩素化合物として除去する方法について 検討し，次の結果が得られた。

1. 金属酸化物と塩素の組み合せで, $\mathrm{MnO}_{2}, \mathrm{PbO}_{2}$ および $\mathrm{CrO}_{3}$ が効果的であり，特に $\mathrm{MnO}_{2}$ がすぐれている。

2. クロルヒドリンとして不飽和化合物を除去する方法は, 塩 素ガスを使用するより効果はあるが，前記方法に少る。

3. 硫酸存在下に塩素ガスを通じる方法は， $\mathrm{MnO}_{2}-\mathrm{HCl}$ 法と 同程度の精製効果があり，有効な方法である。

終りに本研究の発表を許可された秋葉武定理事長ならびに終始 御郎篤な御指導をいたたいた中土晃研究所長, 加藤二郎理事, 有 富勇美部長，実験に滋力いただいた岡田清君，岡部晋君に感謝し ます。 